International Journal of Social Sciences and Humanities
Available online at http://sciencescholar.us/journal/index.php/ijssh
Vol. 2 No. 2, August 2018, pages: $155 \sim 163$
e-ISSN: 2550-7001, p-ISSN: 2550-701X
https://doi.org/10.29332/ijssh.v2n2.155

\title{
Academic Use of Engineering Students in First Semester
} Systems

CrossMark

\section{Ruben Dario Basurto Alcivar a, Gema Monserrate Flores Ormaza ${ }^{\text {b }}$}

Article history: Received 9 February 2018, Accepted in revised form 10 June 2018, Approved 28 July 2018, Available online 7 August 2018

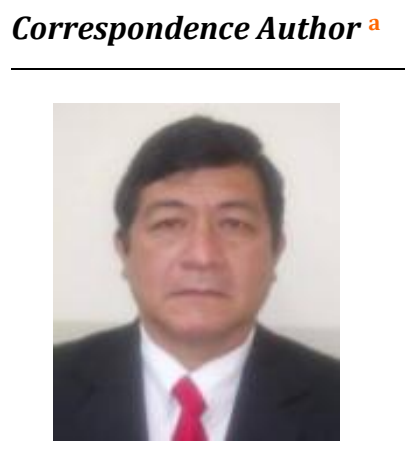

Keywords

Autonomy in learning; Education;

Learning strategies; Self-regulated learning; Systems engineering;

\begin{abstract}
The use of learning strategies facilitates the student's formative process, achieving deep learning related to academic performance. The low amount of work on the learning techniques used by students in engineering training contexts was the motivation to carry out this descriptive exploratory study. The level of utilization of learning skills was investigated to 145 first-semester students, taking into account the academic history of the participants and their availability of time to study, assessing the difference in the use of the different study methods. The data on the use of the learning techniques were obtained through the strategy and motivation questionnaire, which was collected with populations of two academic sections, in the year 2017 and 2018. The corresponding statistical analyzes were carried out that allowed having the results according to the effort made, the economic and social characteristics of each student; the design and results of this research explain the levels of use of learning tactics of participating students; It also allows creating the bases to design future educational interventions in order to promote among students the use of learning skills.
\end{abstract}

e-ISSN : 2550-7001, p-ISSN : 2550-701X ๑ Copyright 2018. The Author. SS Journals Published by Universidad Técnica de Manabí. This is an open-access article under the CC BY-SA 4.0 license (https://creativecommons.org/licenses/by-sa/4.0/) All rights reserved.

\section{Contents}

Abstract

1. Introduction

2. Research Method

3. Results and Analysis 157

4. Conclusion 159

a Systems Engineering Career, Faculty of Computer Science, Universidad Laica Eloy Alfaro de Manabí (ULEAM), Manta, Manabí, Ecuador

b Engineering career in Construction Universidad Tecnica de Manabi, Portoviejo, Manabi, Ecuador 
Conflict of interest statement and funding sources............................................................................................ 160

Statement of authorship ...................................................................................................................................... 160

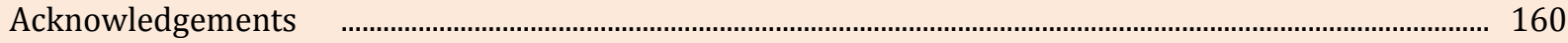

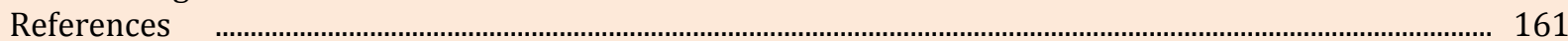

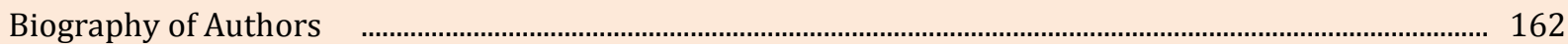

\section{Introduction}

Academic performance is understood as the relationship between the learning process and its tangible results in predetermined values; but, in fact, the complexity of the academic performance begins from its conceptualization because the different denominations of the concept are generally only explained by semantic questions [1].

Pizarro defines the academic performance as a measure of the respondent or indicative capacities, which show, in an estimated way, what a person has learned, as a consequence of an instruction or training process [2]. The same author, from a perspective of the student, needs it as the respondent's ability to respond to educational stimuli, which can be interpreted according to pre-established educational objectives or purposes [3].

In this sense, academic performance becomes an "imaginary table of measure" for the learning achieved by the student, which is the central objective of education [4]. However, in academic performance, many other variables external to the subject are involved, such as the quality of the teacher, the classroom environment, the family, the educational program, and psychological or internal variables, such as attitude towards the subject, intelligence, the personality, among others [5].

Studies about students' learning styles go back to the decades of the 1940s and 1950s. Subsequently, and based on what was reported by the findings of the first studies, research focused on cognitive styles [6]. In the seventies, along with the development of cognitive styles arose the concern of educators and pedagogues to conduct research and studies on how students learn and how this can help in the design of methods and strategies and in the effectiveness of the student's learning [7],[15].

The study was conducted at the Laica Eloy Alfaro de Manabí University (ULEAM). In the institution, the careers of Systems Engineering, Electromechanical Engineering, Electronic Engineering and Renewable Energy Engineering are taught. One of the objectives of the race is to look for alternatives that translate into a better academic development of the students [8]. For this reason, as a strategy to improve the academic performance of its students, the race was considered as a priority to make a diagnosis of the learning styles of its students, as part of an institutional commitment, raised in the educational model of the technological system, implemented in 2003, which demands that students of technological education institutions be comprehensive, of high quality and that promotes autonomous learning [9].

\section{Research Method}

Academic life is defined by the research group as "the set of experiences developed in compliance with curricular and university duties and rights", are associated with diverse variables such as academic performance [10].

For the type of study, this research is descriptive, based on the method of observing the behavior of academic performance and the description of the factors identified [11],[13]. For its philosophical approach is a mixed study, to establish relationships between quantitative and qualitative variables, also diverse opinions of students in the sample investigated were evaluated, according to the method used is observational, where similar results were described [12],[14]. According to the cut in time, it is transversal, due to the period and sequence of the study, included in the period 2017, and it is retrospective because the events occurred and contemplated between 2017 and 2018 were studied. 


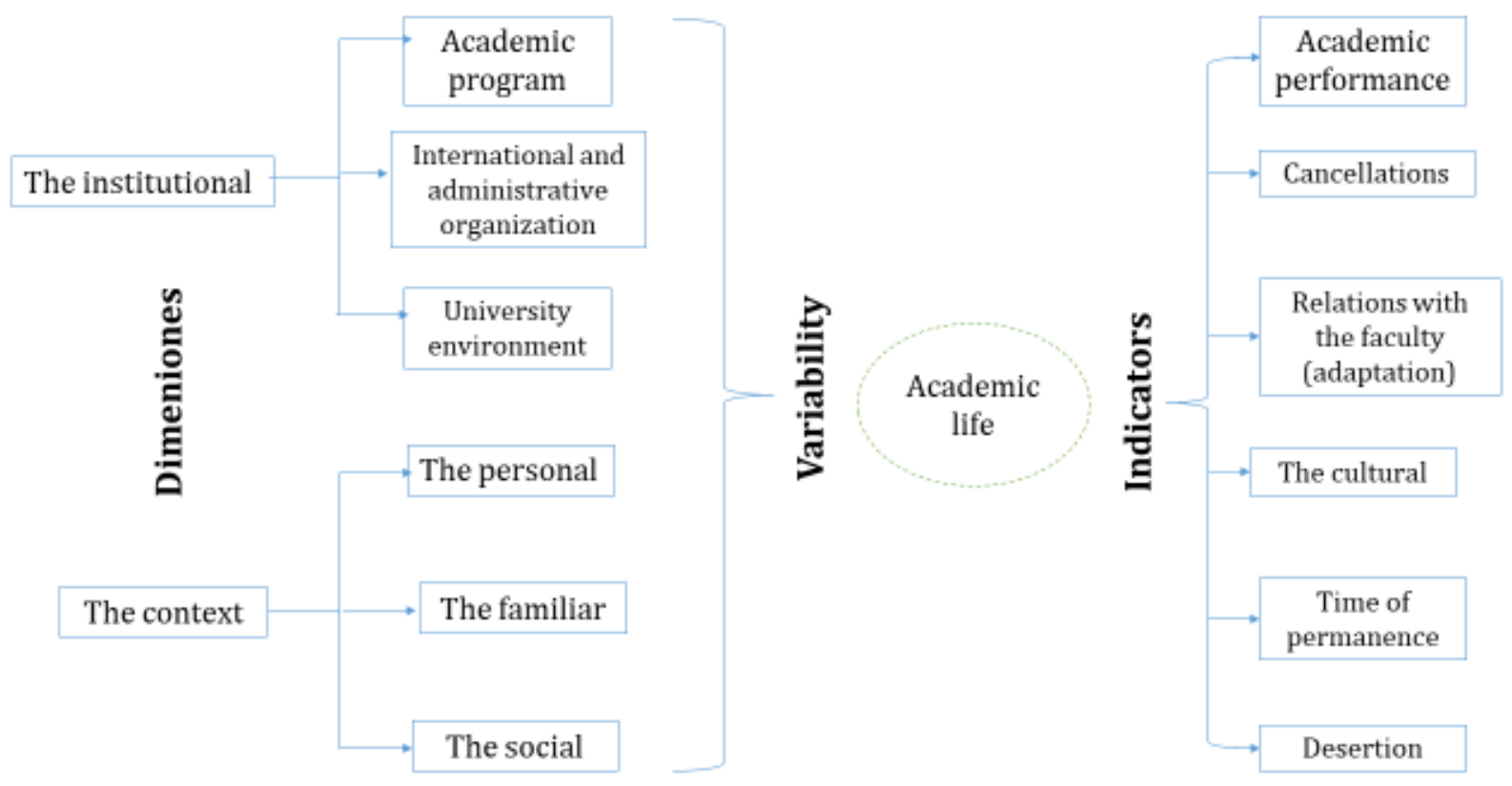

Figure 1. Shows a diagram of the cycle in academic life

\section{Results and Analysis}

A documentary analysis was made with the information contained in the grades obtained, subject registered and subject failed by each student, classified by academic year, covering the period 2017a 2018 with two semesters analyzed. This information allowed to account for the promotion, desertion, and retention of the students of the career.

A sample of 145 students was taken to observe the optimal results of the use and learning shown in Table 1.

Table 1

Number of students in the linear algebra subject

\begin{tabular}{|c|c|c|}
\hline SUBJECT & POPULATION & PERIOD \\
\hline LINEAR ALGEBRA & 94 & $2017-2017$ \\
\hline LINEAR ALGEBRA & 55 & $2017-2018$ \\
\hline
\end{tabular}

\begin{tabular}{|c|c|c|c|}
\hline Modality & On-site & \multicolumn{2}{|c|}{} \\
\hline $\begin{array}{c}\text { Academic } \\
\text { condition }\end{array}$ & Outstanding & Normal & Insufficient \\
\hline $\begin{array}{c}\text { Grade point } \\
\text { average }\end{array}$ & 40 & 28 & 10 \\
\hline
\end{tabular}

Figure 2 shows the results obtained from the documentary analysis applied to describe the behavior of the academic performance of the students of the career. As can be seen in the period in 2017, the levels of use were higher than in the period 2017-2918.

Alcivar, R. D. B., \& Ormaza, G. M. F. (2018). Academic use of engineering students in first semester systems. International Journal of Social Sciences and Humanities, 2(2), 155-163. https://doi.org/10.29332/ijssh.v2n2.155 


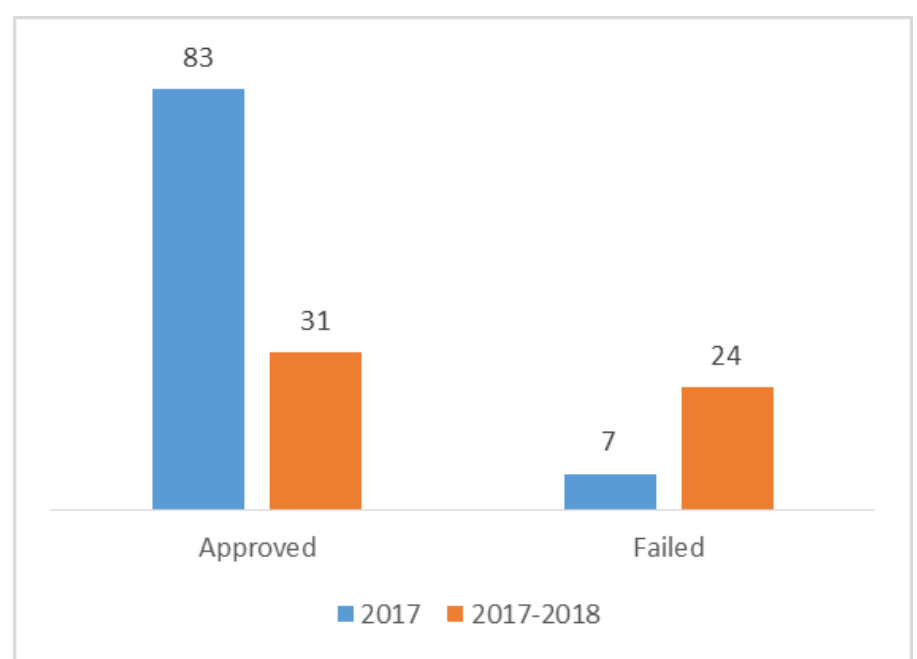

Figure 2. Student academic achievement

Figure 3 shows the percentage of students approved and failed in the two semesters studied, as can be seen, $78.6 \%$ are approved.

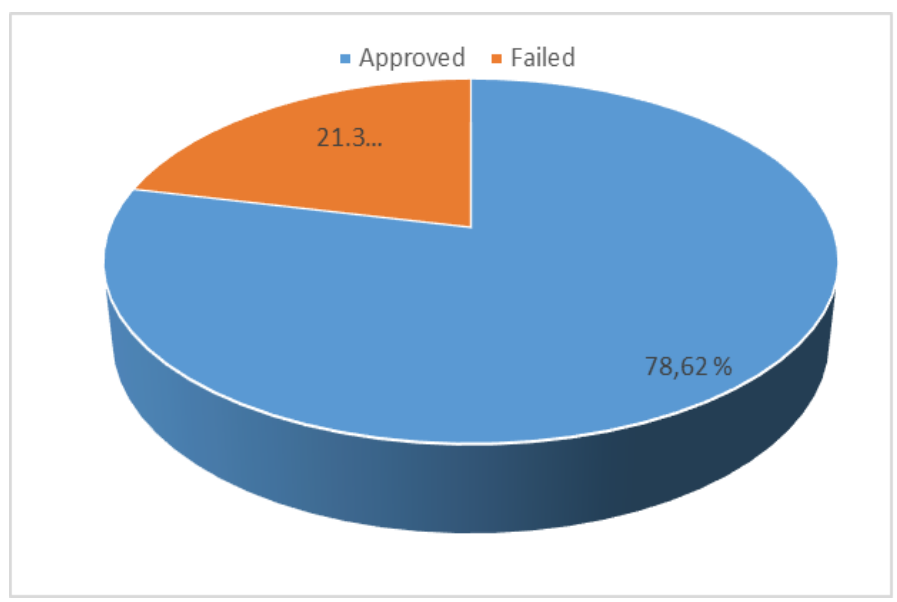

Figure 3. Percentage of use

These results, although they are not very good, show that the levels of achievement must improve, for this, other methods must be applied that allow students better academic performance. As shown in Figure 4, the distribution of residence of students in the System Engineering career indicates that the inhabitants of other cantons are those who have difficulties in the development of teaching-learning. 


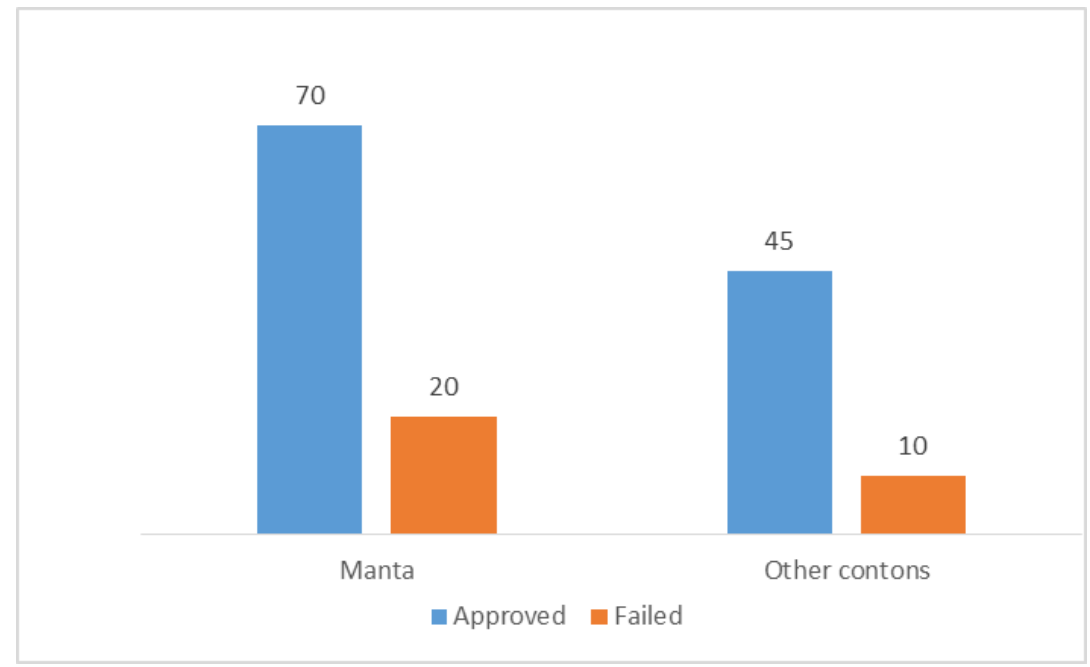

Figure 4. Place of residence of students

As shown in Figure 5, the percentages of academic performance in the 2017 period were relevant to those that occurred in the period 2017-2018; this indicates to look for better skills and abilities so that a better development and academic achievement will flow in the students of System Engineering

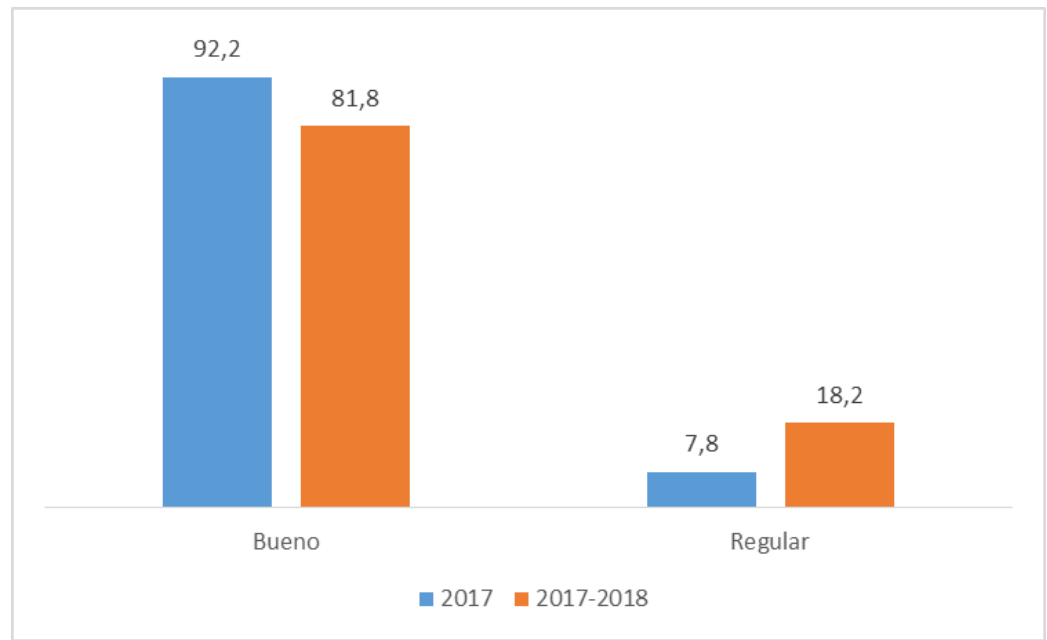

Figure 5. Percentage of teaching and learning

The behavior of students in the teaching-learning system is not the same when they have to travel long distances to reach their universities, mainly those who attend the first university years, because they have to take transports, the time for study decreases, his diet does not have a set schedule; Many of these factors influence your academic performance

\section{Conclusion}

The academic performance of active students presents an average and a pass rate in good standing that increases as the student passes the year. Almost half of the students dropped out of the race, most deserted in the first year of the race.

The determining institutional factors were the complexity of studies, institutional conditions, support services, student-teacher relationship and admission tests.

Alcivar, R. D. B., \& Ormaza, G. M. F. (2018). Academic use of engineering students in first semester systems. International Journal of Social Sciences and Humanities, 2(2), 155-163. https://doi.org/10.29332/ijssh.v2n2.155 
Conflict of interest statement and funding sources

The authors declared that they have no competing interest. The study was financed by independent funding.

Statement of authorship

The authors have a responsibility for the conception and design of the study. The authors have approved the final article.

Acknowledgments

The authors thank to the editor of the journal for their review of suggestion, valuable time, and advice. 


\section{References}

1. Llera, J. B. (2003). Estrategias de aprendizaje. Revista de educación, (332), 55-73.

View in (Google Scholar)

2. Castro, L. I. G., García, G. G., \& Carillo, C. A. C. (2006). Estrategias de aprendizaje utilizadas por los estudiantes con bajo rendimiento académico de $1^{\circ}$ y $2^{\circ}$ semestre de Ingeniería de Sistemas y Telecomunicaciones de la Universidad de Manizales. Revista Educación en Ingeniería, 1(1), 26-36.

View in (Google Scholar)

3. Carretero-Dios, H., \& Pérez, C. (2005). Normas para el desarrollo y revisión de estudios instrumentales. International Journal of clinical and health psychology, 5(3).

View in (Google Scholar)

4. Garcia-Manero, G., Kantarjian, H. M., Sanchez-Gonzalez, B., Yang, H., Rosner, G., Verstovsek, S., ... \& Xiao, L. (2006). Phase $1 / 2$ study of the combination of 5 -aza-2'-deoxycytidine with valproic acid in patients with leukemia. Blood, 108(10), 3271-3279.

View in (Google Scholar)

5. López, B. G., Bertomeu, I. M., Chornet, S. I., Olmedo, M. J. C., Oltra, S. N., \& Félix, E. G. (2014). Metodología centrada en el aprendizaje. Su impacto en las estrategias de aprendizaje y en el rendimiento académico de los estudiantes universitarios. Revista española de pedagogía, 415-435.

View in (Google Scholar)

6. Gargallo, B., Almerich, G., Suárez-Rodríguez, J. M., \& García-Félix, E. (2012). Estrategias de aprendizaje en estudiantes universitarios excelentes y medios. Su evolución a lo largo del primer año de carrera. RELIEVE. Revista Electrónica de Investigación y Evaluación Educativa, 18(2).

View in (Google Scholar)

7. Monereo, C., Pozo, J. I., \& Castelló, M. (2001). La enseñanza de estrategias de aprendizaje en el contexto escolar. Desarrollo psicológico y educación, 2, 235-258.

View in (Google Scholar)

8. Ossa Cornejo, C., \& Aedo Saravia, J. (2014). Enfoques de aprendizaje, autodeterminación y estrategias metacognitivas en estudiantes de pedagogía de una universidad chilena. Ciencias Psicológicas, 8(1), 79-88. View in (Google Scholar)

9. Roces, C., González-Torres, M. C., \& Tourón, J. (1997). Expectativas de aprendizaje y de rendimiento de los alumnos universitarios.

View in (Google Scholar)

10. Roces, C., Tourón, J., \& González-Torres, M. C. (1995). Validación preliminar del CEAM II (Cuestionario de Estrategias de Aprendizaje y Motivación II).

View in (Google Scholar)

11. López, B. G., Bertomeu, I. M., Chornet, S. I., Olmedo, M. J. C., Oltra, S. N., \& Félix, E. G. (2014). Metodología centrada en el aprendizaje. Su impacto en las estrategias de aprendizaje y en el rendimiento académico de los estudiantes universitarios. Revista española de pedagogía, 415-435.

View in (Google Scholar)

12. Aedo, C. (2006, December). Is Allium ebusitanum (Alliaceae) an endemic species from Ibiza?. In Anales del Jardín Botánico de Madrid (Vol. 63, No. 2, pp. 121-130).

View in (Google Scholar)

Alcivar, R. D. B., \& Ormaza, G. M. F. (2018). Academic use of engineering students in first semester systems. International Journal of Social Sciences and Humanities, 2(2), 155-163. https://doi.org/10.29332/ijssh.v2n2.155 
13. Suryasa, I. W., Prayoga, I. G. P. A., \& Werdistira, I. W. A. (2018). Attitudes toward the use of internet for students. International Journal of Physical Sciences and Engineering, 2(2), 32-38.

View in (Google Scholar)

14.Antonio, V. Ã., Vicente, F. Ã., Viteri, C. G. V., \& Molina, L. A. V. (2018). Sustainable Development Seen from Environmental Training in University Linkage. International Journal of Life Sciences, 2(1), 12-20.

View in (Google Scholar)

15. Pérez, A. V., Briones, V. V., Viteri, C. G. V., \& Gámez, M. R. (2017). Iberoamerica in Network, GIS \& TIC. International Journal of Social Sciences and Humanities (IJSSH), 1(3), 108-117.

View in (Google Scholar) 


\section{Biography of Authors}

\begin{tabular}{||l|l||}
\hline \hline & $\begin{array}{l}\text { Rubén Darío, } \\
\text { Professor of education sciences (physics-mathematics specialty) He has received } \\
\text { several national and international courses. } \\
\text { Email: rbasurto59@hotmail.es }\end{array}$ \\
\hline \hline & $\begin{array}{l}\text { Gema Monserrate, } \\
\text { Civil Engineering career of the Faculty of Mathematical, Physical and Chemical } \\
\text { Sciences of the Universidad Técnica de Manabí, she has participated in several } \\
\text { scientific events. } \\
\text { Email: gfloreso4996@gmail.com }\end{array}$ \\
\hline
\end{tabular}

Alcivar, R. D. B., \& Ormaza, G. M. F. (2018). Academic use of engineering students in first semester systems. International Journal of Social Sciences and Humanities, 2(2), 155-163. https://doi.org/10.29332/ijssh.v2n2.155 